\title{
Science centres struggle as funds run out
}

David Adam, London

As the Millennium Dome in London stands empty and forlorn by the River Thames, doubts are growing about the future of a network of science centres set up in Britain as another part of the millennium celebrations.

A dozen or so centres - conceived to boost the public understanding of science, educate children and help to revitalize depressed urban areas - have been built over

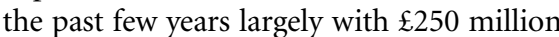
(US\$360 million) raised from Britain's national lottery. But with no more lottery funds available to subsidize them, many of them are already finding the going tough.

Typical difficulties are being confronted this month by the Glasgow Science Centre, which opened last summer in a striking titanium-clad building on the banks of the River Clyde. Already heavily in debt because of delays, cost overruns and technical faults, the centre's trustees agreed at a meeting last week to take $\mathfrak{E} 2$ million from a $\mathfrak{k} 7$-million endowment fund, originally set aside to buy new exhibits, to help balance the books.

The move buys the centre time, but some observers are warning that if public money is not forthcoming, Glasgow and many of the other centres face cutbacks or even closure.

"Without support from government, the future of science centres that do not have income streams other than visitors' spending is bleak," says Linda Conlon, chief executive of the International Centre for Life, a science centre in Newcastle. Her centre hosts exhibitions and even theatre productions on issues

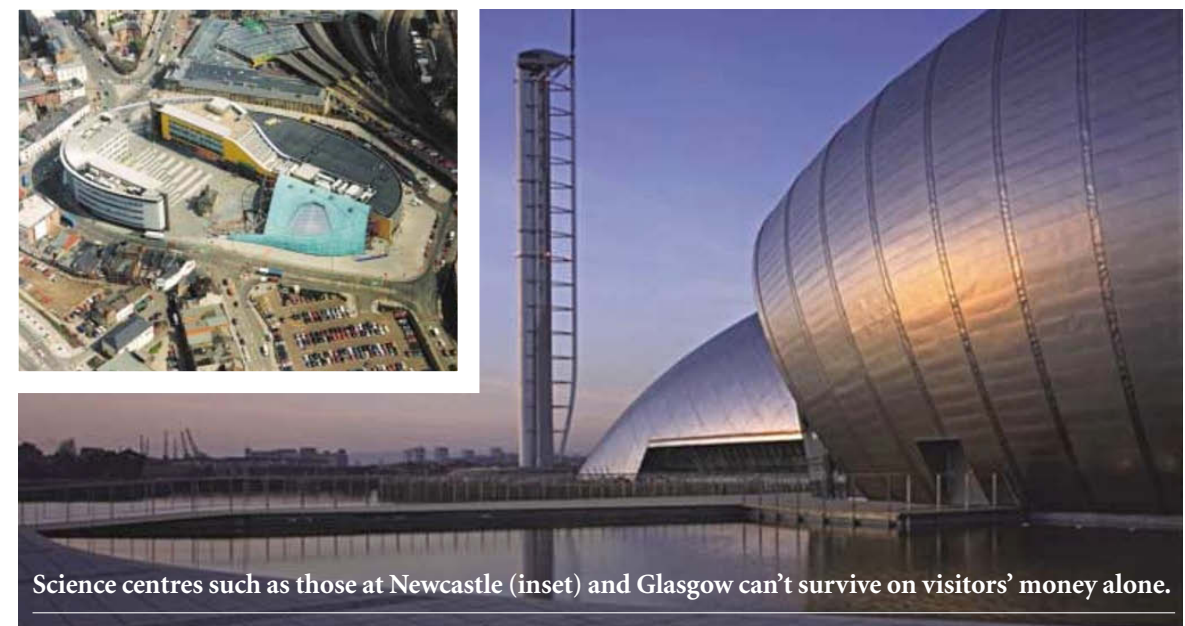

across the life sciences. But it also runs a conference and banqueting business, rents space to local businesses, and hosts the University of Newcastle's Institute of Human Genetics.

"We knew that if we delivered a science centre on its own with no other revenue streams we would be dead within 12 months," Conlon says. She estimates that only about two-thirds of most centres' costs can be met by visitors' admission fees and the money spent in cafeterias and bookshops.

John Durant, chief executive of a centre called at-Bristol, is critical of the model used to set up the centres by the Millennium Commission - the body that allocated lottery money to the projects - in which no money was set aside for future operating costs. "It was always a complete nonsense and they were told at the time it was nonsense," he says. Durant warns that many centres could soon be forced to replace educational activities with more commercial alternatives.

Mike O'Connor, director of the Millennium Commission, says that bidders were told that there would be nolong-term support and that the commission nevertheless "received applications from people who said that their centres would get sufficient visitor numbers and enough income to be viable", he argues.

Melanie Quin, executive director of Ecsiteuk, an umbrella network for the UK centres, admits that the visitor numbers predicted by some of the centres' plans were "wishful thinking”. Quin suggests that the government could step in and pay the centres to play a more direct role in school education.

\section{Environment institute slammed over 'selective' results}

Johanna Schwarz and Alison Abbott, Munich

Germany's science council, the

Wissenschaftsrat, has issued a scathing evaluation of a research institute that has played an important role in influencing the country's energy and environmental policies.

The assessment, which was published last month, says that the Wuppertal Institute near Dusseldorf should redefine its mission and improve the quality of its scientific research — or else no longer receive public money.

The Wuppertal Institute was founded in 1991 by the state of Nordrhein Westfalen which supplies most of its funds - to bridge the gap between basic science and political strategy on environmental issues. But some scientists claim that its research findings have been driven more by ideology than by science.

The Wissenschaftsrat's report, which was requested by the state government, says that some of the institute's departments work well. But the climate department, it says, "follows a one-sided concept, thereby weakening the scientific basis of its political advisory role". It adds that the department gives the impression of being selective in its consideration of research results.

The institute should concentrate on fewer projects, interact more with outside scientists, and publish more of its work in peer-reviewed scientific journals, it recommends.

The Wuppertal Institute says that it will try to comply with the recommendations, but has branded parts of the evaluation as "unfair". It argues that the Wissenschaftsrat has ignored its recent efforts to improve its research and failed to take into account its mission to provide policy advice as well as scientific results.

But Reinhard Hüttl, a soil scientist at the Brandenburg University of Technology in Cottbus who headed the evaluation committee, says that "every important detail of the institute" was considered.

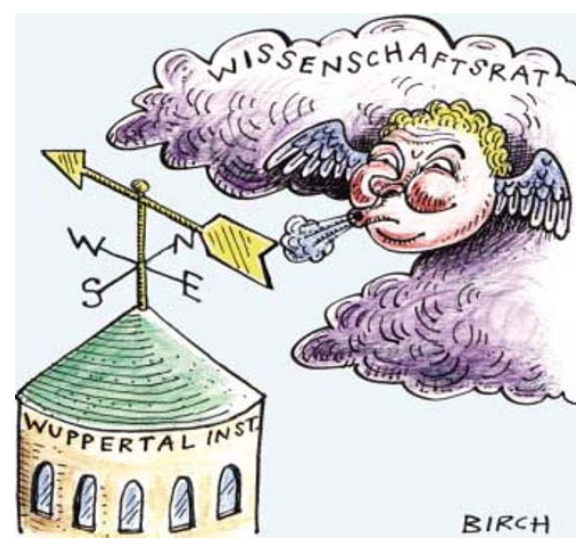

Some scientists have sympathy with the institute's predicament. The institute "was founded to foster public debate on environmental policy, not to produce topnotch research", says Carlo Jäger, a social scientist at the Potsdam Institute for Climate Impact Research. 